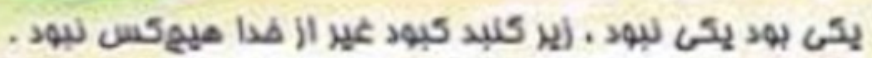

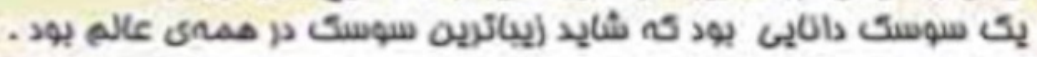

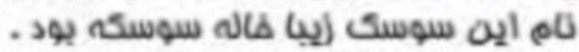

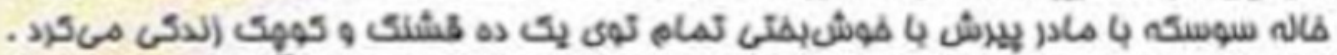

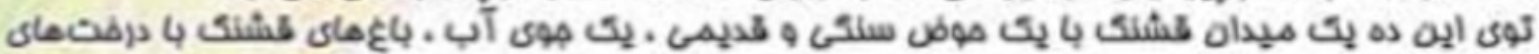

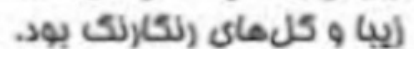

\title{
Frau Kakerlake und Herr Maus
}

\author{
Authors: Mitra Zarif-Kayvan \\ Submitted: $\quad$ 7. January 2018 \\ Published: $\quad$ 10. January 2018 \\ Volume: $\quad 5$ \\ Issue: 1 \\ Languages: German, Persian \\ Keywords: kids, animals, colors, bilingual \\ DOI: $\quad$ 10.17160/josha.5.1.378
}

Journal of Science,

Humanities and Arts 


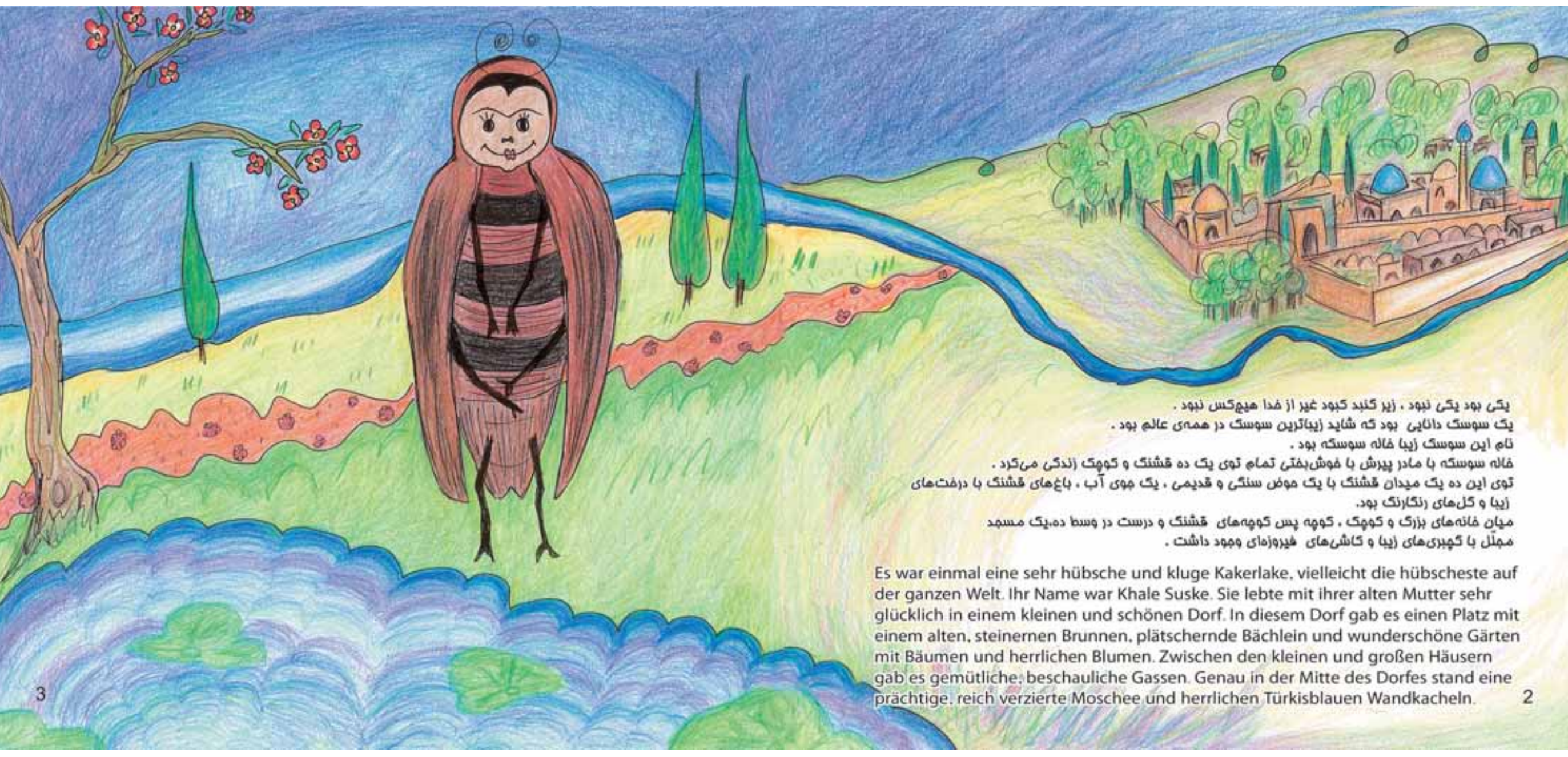




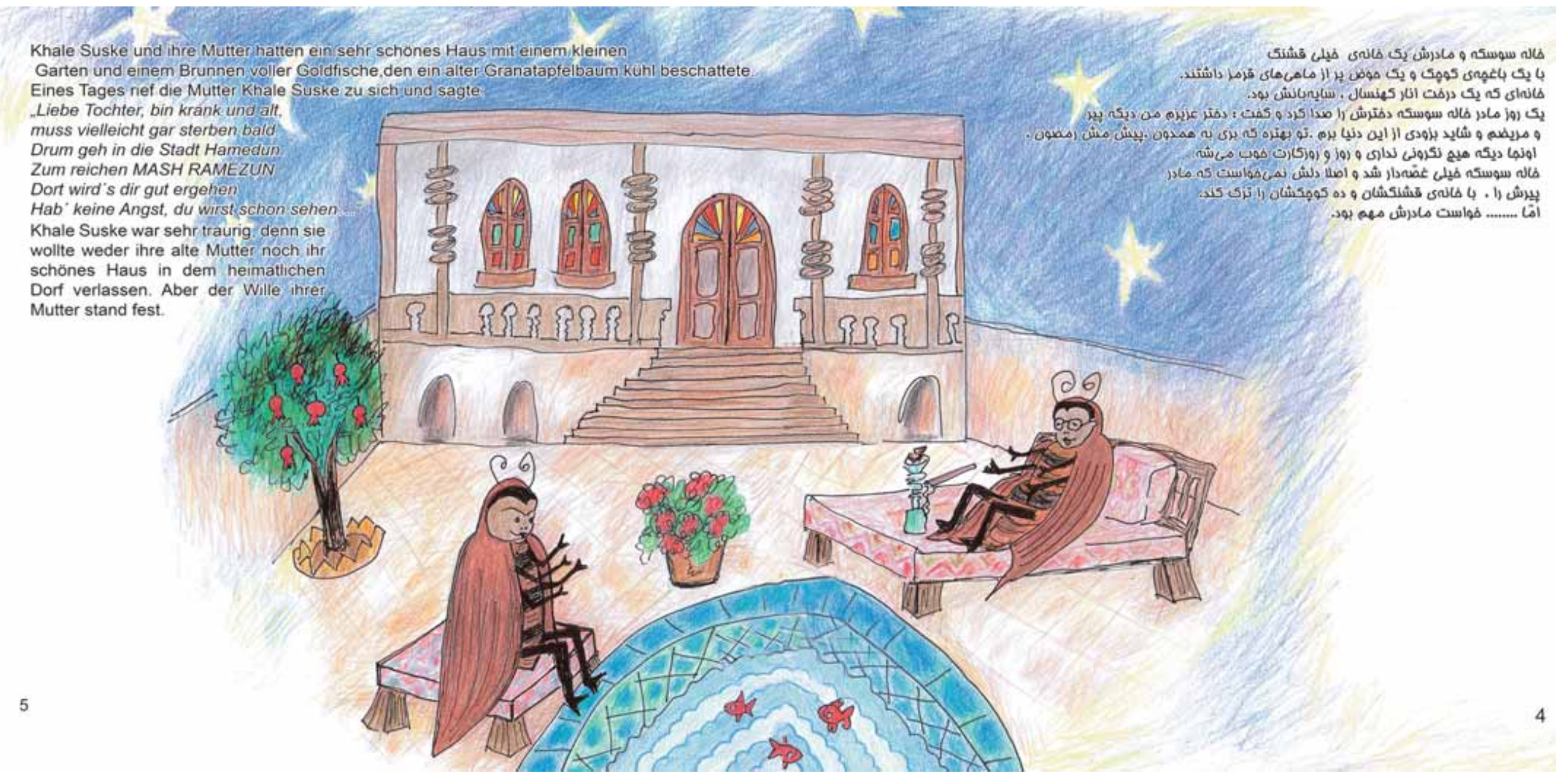

